ArKadiusz Mróz

Uniwersytet Kardynała Stefana Wyszyńskiego

\title{
ZAKOŃCZENIE NAJMU OKAZJONALNEGO I OPRÓŻNIENIE LOKALU
}

\section{WPROWADZENIE}

Artykuł jest ostatnim z trzech artykułów prezentujących szczegółowe rozważania dotyczące konstrukcji najmu okazjonalnego lokalu oraz jej praktycznego znaczenia dla funkcjonowania rynku najmu lokali mieszkalnych w Polsce'.

W artykule przedstawiono rozważania dotyczące zakończenia najmu okazjonalnego i procedury opróżnienia lokalu (eksmisji byłego najemcy).

1 W pierwszym artykule (A. Mróz, Umowa najmu okazjonalnego lokalu, «Zeszyty Prawnicze» 16.4/2016, s. 105-132) wskazano istotę najmu okazjonalnego lokalu i omówiono genezę tej instytucji, przedstawiono także kwestie dotyczące przedmiotu, stron, formy i treści umowy najmu okazjonalnego lokalu oraz terminu, na jaki umowa ta może zostać zawarta, wysokości czynszu i warunków jego podwyższenia, możliwości uzależnienia skuteczności umowy najmu okazjonalnego lokalu od wpłacenia przez najemcę kaucji, jak również treści i charakteru oświadczeń stanowiących załączniki do tej umowy. W drugim artykule (A. Mróz, Zgłoszenie najmu okazjonalnego lokalu naczelnikowi urzędu skarbowego, «Zeszyty Prawnicze» 18.1/2018, s. 25-38) przedstawiono rozważania dotyczące konieczności zgłoszenia przez wynajmującego zawarcia umowy najmu okazjonalnego lokalu naczelnikowi urzędu skarbowego i konsekwencji niedokonania przedmiotowego zgłoszenia. 
W zakończeniu wskazano najważniejsze wnioski, podsumowujące rozważania zawarte we wszystkich trzech opracowaniach.

\section{OSTATNIE ZMIANY W PRZEPISACH DOTYCZĄCYCH NAJMU OKAZJONALNEGO}

Nawiązując do zawartych w pierwszym artykule rozważań dotyczących genezy najmu okazjonalnego lokalu², należy wskazać w tym miejscu na dokonane w ostatnim czasie zmiany w przepisach dotyczących najmu okazjonalnego.

Przepisy ustawy z 21 czerwca 2001 r. o ochronie praw lokatorów, mieszkaniowym zasobie gminy i o zmianie Kodeksu cywilnego (tekst jedn. Dz. U. z 2018 r. poz. 1234 ze zm., dalej: u.o.p.l.) dotyczące najmu okazjonalnego lokalu zostały zmienione przez ustawę z 20 lipca 2017 r. o Krajowym Zasobie Nieruchomości (tekst jedn. Dz. U. z 2018 r. poz. 2363 ze zm.). Wchodzące w życie w dniu 11 września 2017 r. przepisy tej ustawy zmieniły brzmienie art. 19a ust. 1 i 7, art. 19b ust. 1 i 3 oraz art. 19e, jak również uchyliły art. 19a ust. 1a u.o.p.l. ${ }^{3}$ Na skutek powyższych

\section{A. Mróz, Umowa..., s. 106-112.}

Zgodnie ze zmienionym powyższą ustawą brzmieniem art. 19a ust. 7 u.o.p.l., wynagrodzenie notariusza za ogół czynności notarialnych dokonanych przy sporządzaniu oświadczenia, o którym mowa w art. 19a ust. 2 pkt 1 u.o.p.l., wynosiło nie więcej niż maksymalna kwota czynszu normowanego bez opcji za $1 \mathrm{~m} 2$ mieszkania na wynajem, o którym mowa w przepisach ustawy z 20 lipca 2017 r. o Krajowym Zasobie Nieruchomości, określona dla miasta stołecznego Warszawy. Brzmienie art. 19a ust. 7 u.o.p.l. zostało następnie ponowne zmienione ustawą z 5 lipca 2018 r. o ułatwieniach w przygotowaniu i realizacji inwestycji mieszkaniowych oraz inwestycji towarzyszących (Dz. U. poz. 1496 ze zm.). Wynagrodzenie notariusza za sporządzenie oświadczenia, o którym mowa w art. 19a ust. 2 pkt 1 u.o.p.l., wynosi obecnie nie więcej niż 1/10 minimalnego wynagrodzenia za pracę, o którym mowa w ustawie z 10 października 2002 r. o minimalnym wynagrodzeniu za pracę (tekst jedn. Dz. U. z 2018 r. poz. 2177). Zgodnie z $\$ 1$ rozporządzenia Rady Ministrów z 11 września 2018 r. w sprawie wysokości minimalnego wynagrodzenia za pracę oraz wysokości minimalnej stawki godzinowej w 2019 r. (Dz. U. z 2018 r. poz. 1794), minimalne wynagrodzenie za pracę w 2019 r. wynosi 2250 złotych. W związku z tym wynagrodzenie notariusza za sporządzenie przedmiotowego oświadczenia wynosi w 2019 r. nie więcej niż 225 złotych. 
zmian nastąpiło ponowne ograniczenie zakresu stosowania najmu okazjonalnego, w ramach którego de lege lata lokale wynajmować mogą jedynie osoby fizyczne, nieprowadzące działalności gospodarczej w zakresie wynajmowania lokali ${ }^{4}$. Zgodnie z wprowadzonym przez powyższą ustawę brzmieniem art. 19a ust. 1 u.o.p.l., umową najmu okazjonalnego lokalu jest umowa najmu lokalu mieszkalnego ${ }^{5}$, którego właściciel, będący osobą fizyczną, nie prowadzi działalności gospodarczej w zakresie wynajmowania lokali, zawarta na czas oznaczony, nie dłuższy niż 10 lat.

Jednocześnie powyższa ustawa dodała do u.o.p.l. rozdział 2b - „Najem instytucjonalny lokalu” (obejmujący pierwotnie art. 19f-19j u.o.p.l.) oraz art. $25 \mathrm{~d}$ pkt 4 u.o.p.l. Tym samym wprowadzono nowy szczególny rodzaj najmu lokali mieszkalnych - najem instytucjonalny lokalu, który może znaleźć zastosowanie w przypadku, gdy wynajmującym lokal mieszkalny jest osoba fizyczna, osoba prawna lub jednostka organizacyjna niebędąca osobą prawną, prowadząca działalność gospodarczą w zakresie wynajmowania lokali'.

4 Przed omawianą zmianą u.o.p.l. (w okresie od 23 listopada 2013 r. do 10 września 2017 r.) wynajmującym w ramach najmu okazjonalnego mogła być zarówno osoba fizyczna, nieprowadząca działalności gospodarczej w zakresie wynajmowania lokali, jak i osoba fizyczna, osoba prawna lub jednostka organizacyjna prowadząca działalność gospodarczą w takim zakresie. Zgodnie z art. 137 ust. 2 ustawy z 20 lipca 2017 r. o Krajowym Zasobie Nieruchomości do umów najmu okazjonalnego zawartych przed dniem wejścia w życie tej ustawy stosuje się przepisy dotychczasowe.

5 Warto zauważyć jeszcze jedną zmianę w stosunku do poprzedniego brzmienia art. 19a ust. 1 u.o.p.l., zgodnie z którym przedmiotem najmu okazjonalnego mógł być „lokal służący do zaspokajania potrzeb mieszkaniowych”. Zgodnie z obecnym brzmieniem tego przepisu, przedmiotem umowy najmu okazjonalnego jest „lokal mieszkalny”. J. ZAWADZKA (Najem instytucjonalny lokali mieszkalnych, «Monitor Prawniczy» 21/2017, s. 1137), krytycznie oceniając przedmiotową zmianę, jednocześnie trafnie zauważa, że „pojęcie 'lokal mieszkalny’ oznacza to samo, co 'lokal służący do zaspokajania potrzeb mieszkaniowych', o którym mowa w art. 2 ust. 1 pkt 4 OchrLokU”.

${ }^{6}$ De lege lata u.o.p.l. przewiduje zatem dwa szczególne rodzaje najmu lokali mieszkalnych - najem okazjonalny lokalu, gdzie wynajmującym może być jedynie nieprowadząca działalności gospodarczej w zakresie wynajmowania lokali osoba fizyczna, oraz najem instytucjonalny lokalu, w ramach którego wynajmować lokale mieszkalne mogą podmioty (osoby fizyczne, osoby prawne i jednostki organizacyjne) prowadzące działalność gospodarczą w tym zakresie. W ramach najmu instytucjonalnego 
Przepisy dotyczące najmu instytucjonalnego lokalu zostały następnie zmienione przez ustawę z 22 marca 2018 r. o zmianie ustawy o finansowym wsparciu tworzenia lokali socjalnych, mieszkań chronionych, noclegowni i domów dla bezdomnych, ustawy o ochronie praw lokatorów, mieszkaniowym zasobie gminy i o zmianie Kodeksu cywilnego oraz niektórych innych ustaw (Dz. U. z 2018 r. poz. 756) ${ }^{7}$ oraz ustawę z 5 lipca 2018 r. o ułatwieniach w przygotowaniu i realizacji inwestycji mieszkaniowych oraz inwestycji towarzyszących (Dz. U. z 2018 r. poz. 1496), która wprowadziła bardzo daleko idące i istotne zmiany w regulacji dotyczącej najmu instytucjonalnego, zmieniając część dotychczasowych i wprowadzając nowe przepisy (regulacja ta obejmuje obecnie art. 19f-19s u.o.p.l. oraz art. 25d pkt 4 i 5 u.o.p.l. $)^{8}$.

\section{ZAKOŃCZENIE NAJMU OKAZJONALNEGO LOKALU}

Zgodnie z art. 19d ust. 1 u.o.p.l. umowa najmu okazjonalnego lokalu wygasa po upływie czasu, na jaki była zawarta, lub ulega rozwiązaniu po upływie okresu wypowiedzenia tej umowy ${ }^{9}$. Wynikający z umowy najmu okazjonalnego lokalu stosunek prawny ustaje na skutek nadejścia

wyróżniamy obecnie także najem instytucjonalny z dojściem do własności lokalu. Konstrukcję najmu instytucjonalnego lokalu szerzej przedstawia m.in. J. ZAwADZKA (op. cit., s. 1133-1146).

7 Zmiana ta dotyczyła brzmienia art. 19 f ust. 3 u.o.p.l., wejdzie ona w życie w dniu 21 kwietnia 2019 r.

8 Skutkiem wprowadzonych przez tę ustawę zmian było wprowadzenie do systemu prawnego szczególnego rodzaju umowy najmu instytucjonalnego, jaką jest umowa najmu instytucjonalnego $\mathrm{z}$ dojściem do własności lokalu (art. 19k-19s u.o.p.l.).

9 J. PAnowicz-Lipska ([w:] System Prawa Prywatnego. Prawo zobowiązań - część szczegółowa, VIII, red. J. PANowiCz-Lipska, Warszawa 2011, s. 175) słusznie zauważa, że „przepis art. 19d ust. 1 (...) jest przepisem zbędnym, a ponadto mylącym, ponieważ zakończenie najmu okazjonalnego lokalu może nastąpić także w następstwie innych zdarzeń, np. rozwiązanie stosunku najmu przez sąd (art. 13 OchrLokU), wypowiedzenie najmu przez najemcę ze skutkiem natychmiastowym (art. $664 \$ 2 \mathrm{KC)}$ ). J. ZAWADZKA (op. cit., s. 1143) słusznie zauważa, że „możliwe jest także wygaśnięcie stosunku najmu na skutek konfuzji, gdy najemca nabędzie własność lokalu, z którego korzysta na podstawie umowy najmu”. 
wskazanego w niej terminu końcowego lub w wyniku wypowiedzenia tej umowy. Należy w tym miejscu przypomnieć, że umowa najmu okazjonalnego lokalu może zostać zawarta na czas określony, nie dłuższy niż 10 lat. Z kolei wypowiedzenie umowy najmu okazjonalnego lokalu jest możliwe w przypadkach określonych w art. 11 ust. 2 pkt 1-3 oraz art. 19 d ust. 5 u.o.p.l. ${ }^{10}$

Zgodnie z art. 11 ust. 2 pkt 1-3 u.o.p.l., nie później niż na miesiąc naprzód, na koniec miesiąca kalendarzowego, właściciel może wypowiedzieć stosunek prawny, jeżeli lokator: pomimo pisemnego upomnienia nadal używa lokalu w sposób sprzeczny z umową lub niezgodnie z jego przeznaczeniem lub zaniedbuje obowiązki, dopuszczając do powstania szkód, lub niszczy urządzenia przeznaczone do wspólnego korzystania przez mieszkańców albo wykracza w sposób rażący lub uporczywy przeciwko porządkowi domowemu, czyniąc uciążliwym korzystanie z innych lokali, lub jest w zwłoce z zapłatą czynszu lub innych opłat za używanie lokalu co najmniej za trzy pełne okresy płatności pomimo uprzedzenia go na piśmie o zamiarze wypowiedzenia stosunku prawnego i wyznaczenia dodatkowego, miesięcznego terminu do zapłaty zaległych i bieżących należności ${ }^{11}$, lub wynajął, podnajął albo oddał do

10 K. Zdun-ZAŁĘSKA, Ustawa o ochronie praw lokatorów, mieszkaniowym zasobie gminy i o zmianie Kodeksu cywilnego. Komentarz, Warszawa 2014, s. 146; E. BończAK-KuCHARCzyк, Ochrona praw lokatorów i najem lokali mieszkalnych. Komentarz, Warszawa 2013, s. 336; A. KAźMIERCzy , Najem okazjonalny lokali mieszkalnych w świetle zasady swobody umów, [w:] Ustawowe ograniczenia swobody umów. Zagadnienia wybrane, red. B. Gnela, Warszawa 2010, s. 511; J. CHAcińsKi, Ochrona praw lokatorów. Komentarz, Warszawa 2013, s. 158; R. DziczeK, Ochrona praw lokatorów. Dodatki mieszkaniowe. Komentarz. Wzory pozwów, Warszawa 2012, s. 149; Tenże, Prawo mieszkaniowe w praktyce. Wzory pozwów i wniosków sądowych, Warszawa 2012, s. 406; P. SŁAWICKI, P. Widerski, Najem okazjonalny lokali - cz. II, «Monitor Prawniczy» 8/2012, s. 409.

11 Brzmienie art. 11 ust. 2 pkt 2 u.o.p.l. zostało zmienione przez ustawę z 22 marca 2018 r. o zmianie ustawy o finansowym wsparciu tworzenia lokali socjalnych, mieszkań chronionych, noclegowni i domów dla bezdomnych, ustawy o ochronie praw lokatorów, mieszkaniowym zasobie gminy i o zmianie Kodeksu cywilnego oraz niektórych innych ustaw (Dz. U. poz. 756). Zgodnie z nowym brzmieniem tego przepisu nie później niż na miesiąc naprzód, na koniec miesiąca kalendarzowego, właściciel może wypowiedzieć stosunek prawny, jeżeli lokator jest w zwłoce z zapłatą czynszu, innych opłat za 
bezpłatnego używania lokal lub jego część bez wymaganej pisemnej zgody właściciela ${ }^{12}$.

Wypowiedzenie najmu okazjonalnego lokalu jest także możliwe w sytuacji określonej w art. 19d ust. 5 u.o.p.l. Zgodnie z tym przepisem, w przypadku niedopełnienia przez najemcę obowiązku, o którym mowa w art. 19a ust. 3 u.o.p.l., właściciel lokalu może wypowiedzieć na piśmie umowę najmu okazjonalnego lokalu, z zachowaniem co najmniej siedmiodniowego okresu wypowiedzenia. Zgodnie z art. 19a ust. 3 u.o.p.l., w razie utraty możliwości zamieszkania w lokalu wskazanym w oświadczeniu najemcy (o którym mowa w art. 19a ust. 2 pkt 2 u.o.p.l.), w którym to lokalu najemca miał móc zamieszkać w przypadku wykonania egzekucji obowiązku opróżnienia lokalu, najemca jest obowiązany w terminie 21 dni od dnia powzięcia wiadomości o tym zdarzeniu wskazać inny lokal, w którym mógłby zamieszkać w przypadku wykonania egzekucji obowiązku opróżnienia lokalu, oraz przedstawić oświadczenie właściciela tego lokalu lub osoby posiadającej tytuł prawny do tego lokalu, o wyrażeniu zgody na zamieszkanie najemcy i osób z nim zamieszkujących w lokalu wskazanym w tym oświadczeniu (oświadczenie, o którym mowa w art. 19a ust. 2 pkt 3 u.o.p.l.). Konsekwencją niewykonania przez najemcę powyższego obowiązku jest możliwość dokonania przez wynajmującego wypowiedzenia umowy najmu okazjonalnego na zasadach wskazanych w art. $19 \mathrm{~d}$ ust. 5 u.o.p.l.

Oświadczenie wynajmującego wypowiadające najem okazjonalny lokalu na podstawie art. 19d ust. 5 u.o.p.l. powinno zostać złożone w formie pisemnej (forma ta zastrzeżona jest ad probationem - art. $73 \$ 1$ k.c.)

używanie lokalu lub opłat niezależnych od właściciela pobieranych przez właściciela tylko w przypadkach, gdy lokator nie ma zawartej umowy bezpośrednio z dostawcą mediów lub dostawcą usług, co najmniej za trzy pełne okresy płatności pomimo uprzedzenia go na piśmie o zamiarze wypowiedzenia stosunku prawnego i wyznaczenia dodatkowego, miesięcznego terminu do zapłaty zaległych i bieżących należności. Zmiana brzmienia tego przepisu wejdzie w życie w dniu 21 kwietnia 2019 r.

12 J. CHACIŃski (op. cit., s. 158) słusznie zauważa, że ,utrzymanie stosowania art. 11 ust. 2 pkt 1-3 OchrLokU jest formą ochrony najemcy, gdyż stosownie do przepisów KC zdarzenia wskazane w art. 11 ust. 2 pkt 1-3 OchrLokU uzasadniają wypowiedzenie najmu bez zachowania terminów wypowiedzenia (art. $667 \$ 2$, art. 685 i $687 \mathrm{KC)}$ )”. 
oraz powinno ono wskazywać, nie krótszy niż siedmiodniowy, termin wypowiedzenia umowy.

Przewidziana w art. 19d ust. 5 u.o.p.l. możliwość wypowiedzenia przez wynajmującego umowy najmu okazjonalnego lokalu jest obiektem zdecydowanej krytyki. W literaturze wskazuje się między innymi, że wypowiedzenie to uzależnione jest od wystąpienia okoliczności, które mogą być niezależne od najemcy i całkowicie przez niego niezawinione. Ponadto, wypowiedzenie umowy najmu okazjonalnego w przedmiotowych okolicznościach może prowadzić do sytuacji, w której najemca będzie zmuszony do opuszczenia lokalu (w którym mieszkał na podstawie umowy najmu okazjonalnego), a jednocześnie de facto nie będzie miał dokąd się przeprowadzić, co w ostateczności może zakończyć się jego eksmisją do noclegowni, schroniska lub innej placówki zapewniającej miejsca noclegowe ${ }^{13}$.

Umowa najmu okazjonalnego lokalu może zostać wypowiedziana także w innych - wskazanych w jej treści - przypadkach. Zgodnie bowiem $z$ art. $673 \$ 3$ k.c., jeżeli czas trwania najmu jest oznaczony,

13 K. Zdun-ZaŁęSKA (op. cit., s. 147) stwierdza, że „wprowadzenie do ustawy takiej przyczyny wypowiedzenia jest niezrozumiałe, gdyż odnosi się do zdarzenia losowego, na które najemca nie ma wpływu i które jest przez niego niezawinione”. E. BoŃCZAK-KUCHARCZYK (op. cit., s. 336) zauważa z kolei, że „omawiany przepis przynosi więc taki skutek, że jeżeli podczas trwania najmu okazjonalnego najemca utraci możliwość zamieszkania w innym lokalu (jaką wskazał w chwili zawierania umowy o najem okazjonalny), to może za to zostać dodatkowo ukarany prawie natychmiastową utratą prawa do korzystania z lokalu, który wynajmuje na podstawie umowy o najem okazjonalny”. Autorka ta wskazuje również (op. cit., s. 325), że „wydaje się to sprzeczne nie tylko z ideą ochrony praw lokatora, lecz także z ogólnymi zasadami dotyczącymi umów, w których nie powinny się znajdować postanowienia karzące stronę umowy za wystąpienie zjawisk od niej niezależnych. I chociaż w tym przypadku kara wynika wprost z przepisu ustawy (może nie być o niej mowy w umowie), to przepis ten nakłada przykre sankcje na najemcę z powodu utraty prawa zamieszkania w innym lokalu, co mogło być zdarzeniem, na które najemca nie miał wpływu. W związku z nagłą utratą praw do obu mieszkań może się on też znaleźć bez jakiegokolwiek lokum, gdyż w przypadku najmu okazjonalnego w razie eksmisji byłemu najemcy nie przysługuje nawet prawo do pomieszczenia tymczasowego (...)". 
zarówno wynajmujący, jak i najemca mogą wypowiedzieć najem w wypadkach określonych w umowie ${ }^{14}$.

Stosunek najmu okazjonalnego lokalu może także zostać rozwiązany przez sąd. Do umowy najmu okazjonalnego znajduje bowiem również zastosowanie art. 13 u.o.p.l. Zgodnie z tym przepisem, jeżeli lokator wykracza w sposób rażący lub uporczywy przeciwko porządkowi domowemu, czyniąc uciążliwym korzystanie z innych lokali w budynku, inny lokator lub właściciel innego lokalu w tym budynku może wytoczyć powództwo o rozwiązanie przez sąd stosunku prawnego uprawniającego do używania lokalu i nakazanie jego opróżnienia. Z kolei współlokator może wytoczyć powództwo o nakazanie przez sąd eksmisji małżonka, rozwiedzionego małżonka lub innego współlokatora tego samego lokalu, jeżeli ten swoim rażąco nagannym postępowaniem uniemożliwia wspólne zamieszkiwanie.

Trzeba jednocześnie zauważyć, że umowa najmu okazjonalnego lokalu może także zostać zgodnie rozwiązana przez jej strony w drodze stosownego porozumienia. W takim przypadku wynikający z niej stosunek najmu okazjonalnego wygasa w terminie i na warunkach wskazanych w takim porozumieniu.

14 E. Bończak-Kucharczy к, op. cit., s. 337; J. CHACiński, op. cit., s. 158. Odmienne stanowisko prezentuje M. WAGEMANN (Najem okazjonalny, «Nieruchomości» 8/2013, s. 12), który stwierdza, że „strony umowy najmu okazjonalnego nie mogą wprowadzić do umowy postanowień, zgodnie z którymi będą one uprawnione do rozwiązania umowy za wypowiedzeniem w dowolnym momencie obowiązywania umowy”. A. KAźMIERCZYK (op. cit., s. 511) wskazuje z kolei, że „możliwość wypowiedzenia umowy najmu okazjonalnego przez najemcę można wywodzić z przepisów k.c. Nie ma zatem przeszkód co do uczynienia zastrzeżenia w umowie, że najemca lokalu będzie mógł wypowiedzieć najem z określonych przyczyn (art. $673 \$ 3$ k.c.). Dodatkowo na mocy art. $664 \$ 2$ k.c., jak też art. 682 k.c., najemca może wypowiedzieć umowę ze skutkiem natychmiastowym $\mathrm{z}$ uwagi na wady najętego lokalu. Możliwość wypowiedzenia umowy przez wynajmującego kształtuje się odmiennie. Nie znajdzie tu zastosowania instytucja wypowiedzenia najmu zawartego na czas oznaczony w wypadkach określonych w umowie (art. $673 \$ 3$ k.c.). Wynajmujący może wypowiedzieć najem okazjonalny lokalu jedynie z przyczyn określonych w u.o.p.l.”. 


\section{OpróżNIENIE LOKALU - EKSMISJA BYŁego NAJEMCY}

Zakończenie najmu okazjonalnego lokalu wiąże się z koniecznością zwrotu jego przedmiotu wynajmującemu (art. $675 \$ 1$ k.c. w zw. z art. 680 k.c.). Zobowiązanie to obejmuje obowiązek opuszczenia i opróżnienia lokalu przez najemcę i osoby wraz z nim zamieszkujące (wyprowadzenia się z lokalu, a także usunięcia z niego rzeczy najemcy oraz zamieszkujących z nim osób) ${ }^{15}$.

W przypadku niewykonania przez najemcę powyższego zobowiązania wynajmujący uprawniony jest do dochodzenia opróżnienia lokalu. Zgodnie z art. 19d ust. 2 u.o.p.l., po wygaśnięciu lub rozwiązaniu umowy najmu okazjonalnego lokalu, jeżeli najemca dobrowolnie nie opróżnił lokalu, właściciel doręcza najemcy żądanie opróżnienia lokalu, sporządzone na piśmie opatrzonym urzędowo poświadczonym podpisem właściciela ( $\mathrm{z}$ treści powyższego przepisu wynika, że forma pisemna z podpisem urzędowo poświadczonym zastrzeżona jest dla żądania wynajmującego ad solemnitatem - art. $73 \$ 2$ k.c.).

Konieczną treść żądania opróżnienia lokalu określa art. 19d ust. 3 u.o.p.l. Zgodnie z tym przepisem, żądanie opróżnienia lokalu zawiera w szczególności: oznaczenie właściciela oraz najemcy, którego żądanie dotyczy; wskazanie umowy najmu okazjonalnego lokalu i przyczynę ustania stosunku z niej wynikającego; termin, nie krótszy niż siedem dni od dnia doręczenia żądania najemcy, w którym najemca i osoby z nim zamieszkujące mają opróżnić lokal. Wynajmujący musi zatem w kierowanym do najemcy żądaniu opróżnienia lokalu podać dane dotyczące jego osoby oraz dane najemcy, do którego żądanie jest kierowane, wskazać informacje dotyczące umowy najmu okazjonalnego (np. datę i miejsce jej zawarcia oraz jej przedmiot) oraz przyczyn jej wygaśnięcia lub rozwiązania (upływ czasu, na jaki umowa była zawarta, upływ okresu wypowiedzenia umowy, rozwiązanie umowy w drodze

15 K. Zdun-ZaŁęSKa, op. cit., s. 146; E. BońCZAK-KuCHARCZYK, op. cit., s. 337; M. WalasıK, Poddanie się egzekucji przez najemcę okazjonalnego, «Rejent» 3/2011, s. 111; A. Doliwa, Najem lokali. Komentarz, Warszawa 2014, s. 342-343; Tenże, Prawo mieszkaniowe. Komentarz, Warszawa 2012, s. 257; J. CHAcı́́ski, op. cit., s. 159; P. SŁAWiCki, P. Widerski, Najem..., cz. II, s. 409; M. Wagemann, op. cit., s. 12. 
porozumienia stron), a także wyznaczyć najemcy, nie krótszy niż siedmiodniowy, termin, w którym najemca i osoby z nim zamieszkujące mają opróżnić lokal. Termin ten biegnie od dnia doręczenia tego żądania najemcy (chwilę doręczenia tego oświadczenia należy ustalić zgodnie z treścią art. $61 \$ 1$ k.c. $)^{16}$.

Charakterystyczne dla umowy najmu okazjonalnego lokalu jest to, że w przypadku nieopróżnienia lokalu przez najemcę w terminie wyznaczonym do tego w powyższym żądaniu, wynajmujący nie musi wytaczać powództwa o eksmisję najemcy (usunięcie go z lokalu jest możliwe bez konieczności uzyskania wyroku eksmisyjnego). Podstawą przymusowego opróżnienia lokalu jest bowiem w takim wypadku zaopatrzony w klauzulę wykonalności akt notarialny (stanowiący załącznik do umowy), w którym najemca poddał się egzekucji i zobowiązał się do opróżnienia i wydania lokalu używanego na podstawie umowy najmu okazjonalnego lokalu w terminie wskazanym w żądaniu, o którym mowa w art. 19d ust. 2 u.o.p.l. (żądaniu opróżnienia lokalu) ${ }^{17}$.

16 R. Dziczek (Ochrona..., s. 150, oraz Prawo..., s. 407), stojąc na stanowisku, że załączenie do umowy najmu okazjonalnego lokalu oświadczeń, o których mowa w art. 19a ust. 2 i 3 u.o.p.l., nie jest obligatoryjne, zauważa, że „formalizm wypowiadania umowy najmu okazjonalnego lokalu oraz zgłaszania żądania opróżnienia tego lokalu przez dotychczasowego najemcę nie jest konieczny, jeżeli strony umowy nie przewidziały dobrowolnego poddania się najemcy eksmisji z lokalu na podstawie dokumentów, o których mowa w art. 19a ust. 2 i 3”. Autor ten dodaje, że „w przypadku zaś gdy właściciel z takich możliwości nie korzysta, żądanie opróżnienia lokalu nie musi być tak sformalizowane, aby wywołać skutek prawny".

17 K. Zdun-ZaŁęSKa, op. cit., s. 146; J. ChACiński, op. cit., s. 152; P. SŁAWicki, P. Widerski, Najem okazjonalny lokali - cz. I, «Monitor Prawniczy» 7/2012, s. 356; M. WAlasik, op. cit., s. 102; D. DANILUK, Najem okazjonalny w świetle nowelizacji Kodeksu postępowania cywilnego z 31 sierpnia 2011 r., «Radca Prawny» 125/2012 - Dodatek Naukowy, s. 17 D; T. Lechow ICz, Sytuacja wynajmu mieszkań na rynku nieruchomości w Polsce, «Nieruchomości» 5/2011, s. 34; M. Wagemann, op. cit., s. 12-13; D. PiwoWARCZYк, Najem okazjonalny. Czynności notarialne przy zawieraniu umowy najmu okazjonalnego. Analiza aktualnego stanu prawnego, «Jurysta» 1/2010, s. 36; J. PIECH, Prowadzenie egzekucji z najmu okazjonalnego, [w:] Tendencje prawa materialnego i procesowego cywilnego, red. E. MarszaŁKowska-Krześ, Wrocław 2017, s. 196. J. PANOWICZ-Lipska (op. cit., s. 176) zauważa, że „posłużenie się przez wynajmującego tytułem egzekucyjnym w postaci aktu notarialnego (...) ułatwia wynajmującemu 
W celu nadania powyższemu aktowi notarialnemu klauzuli wykonalności wynajmujący powinien złożyć do sądu stosowny wniosek ${ }^{18}$. Zgodnie $\mathrm{z}$ art. $19 \mathrm{~d}$ ust. 4 u.o.p.l., w przypadku bezskutecznego upływu terminu, o którym mowa w art. 19d ust. 3 pkt 3 u.o.p.l. (terminu wskazanego przez wynajmującego w żądaniu opróżnienia lokalu, w którym najemca i osoby z nim zamieszkujące mają opróżnić lokal), właściciel składa do sądu wniosek o nadanie klauzuli wykonalności aktowi notarialnemu, o którym mowa w art. 19a ust. 2 pkt 1 u.o.p.l. Do wniosku załącza się: żądanie opróżnienia lokalu wraz z dowodem jego doręczenia najemcy albo dowodem wysłania go przesyłką poleconą; dokument potwierdzający przysługujący właścicielowi tytuł prawny do lokalu, którego opróżnienia dotyczy żądanie właściciela; potwierdzenie zgłoszenia, o którym mowa w art. 19b ust. 1 u.o.p.l. (zgłoszenia zawarcia umowy najmu okazjonalnego lokalu naczelnikowi urzędu skarbowego). Wraz z powyższym wnioskiem należy złożyć do sądu także odpis aktu notarialnego, o którym mowa w art. 19a ust. 2 pkt 1 u.o.p.l. ${ }^{19}$.

Akt notarialny obejmujący oświadczenie, o którym mowa w art. 19a ust. 2 pkt 1 u.o.p.l., jest tytułem egzekucyjnym (art. $777 \$ 1$ pkt 4 k.p.c. ${ }^{20}$ ),

odzyskanie władztwa nad lokalem, ale nie jest wyłącznym sposobem prowadzącym do tego celu. Wynajmujący może, chociaż istnieje wspomniany akt notarialny, wytoczyć powództwo o opróżnienie i wydanie lokalu (w niektórych przypadkach będzie to potrzebne, np. gdy ustanie stosunku najmu jest między stronami sporne) i prowadzić egzekucję z wykorzystaniem prawomocnego wyroku jako tytułu egzekucyjnego. Ponieważ mówimy tu o najmie okazjonalnym zgłoszonym w urzędzie skarbowym, w procesie nie będą miały zastosowania przepisy art. 14 i 15 OchrLokU (...), w tym co do orzekania o uprawnieniu do lokalu socjalnego".

18 Treść wniosku o nadanie klauzuli wykonalności oraz przebieg postępowania w przedmiotowej sprawie szczegółowo omawia M. WALAsiK (op. cit., s. 116-121).

19 K. Zdun-ZA£ĘSKA, op. cit., s. 146-147; E. BońCZAK-KuCHARCZYK, op. cit., s. 337338; A. Doliwa, Najem..., s. 343; Tenże, Prawo..., s. 257; M. Wagemann, op. cit., s. 12. J. PIECH (op. cit., s. 196) zauważa, że „wykonanie zatem obowiązku wynikającego z art. $777 \$ 1$ pkt 4 k.p.c. uzależnione zostało od szeregu zdarzeń jak: wygaśnięcie, rozwiązanie umowy najmu czy doręczenie przez właściciela żądania opróżnienia lokalu i upływ określonego w nim terminu, nie krótszego niż 7 dni”.

${ }^{20}$ Zgodnie $\mathrm{z}$ art. $777 \$ 1$ pkt 4 k.p.c., tytułem egzekucyjnym jest akt notarialny, w którym dłużnik poddał się egzekucji i który obejmuje obowiązek zapłaty sumy pieniężnej lub wydania rzeczy oznaczonych co do gatunku, ilościowo w akcie określonych, 
który po zaopatrzeniu w klauzulę wykonalności staje się tytułem wykonawczym i stanowi podstawę egzekucji (art. 776 k.p.c.). Umożliwia on zatem wystąpienie do komornika o wszczęcie egzekucji sądowej i opróżnienie lokalu ${ }^{21}$. Tryb postępowania komornika określa wydane na podstawie art. $1046 \$ 11$ k.p.c. rozporządzenie Ministra Sprawiedliwości z 22 grudnia 2011 r. w sprawie szczegółowego trybu postępowania w sprawach o opróżnienie lokalu lub pomieszczenia albo o wydanie nieruchomości (Dz. U. z 2012 r. poz. 11)22.

Zgodnie $\mathrm{z}$ art. $1046 \$ 4$ k.p.c. ${ }^{23}$, wykonując obowiązek opróżnienia lokalu służącego zaspokojeniu potrzeb mieszkaniowych dłużnika na

albo też wydania rzeczy indywidualnie oznaczonej, gdy w akcie wskazano termin wykonania obowiązku lub zdarzenie, od którego uzależnione jest wykonanie.

${ }^{21}$ K. Zdun-ZaŁęSKa, op. cit., s. 146; J. Chaciński, op. cit., s. 159; J. PANOWiCZ-Lipska, op. cit., s. 176; M. WALAsik, op. cit., s. 102; P. SŁAWICKi, P. WidersKi, Najem..., cz. II, s. 411; D. DANiluk, op. cit., s. 17 D; T. LeChowicz, op. cit., s. 34; M. WAGEMANn, op. cit., s. 11; J. PIECH, op. cit., s. 196.

22 E. SiwIŃsKA-BECK (Najem okazjonalny - wybrane zagadnienia praktyczne, «Nieruchomości» 7/2017, s. 46-47) zauważa, że „osoby wynajmujące lokale nadal borykają się z utrudnioną i długotrwałą eksmisją (...). Dzieje się tak m.in. dlatego, że niektórzy nieuczciwi najemcy doskonale rozeznani w przepisach prawa lokalowego wykorzystują wszystkie meandry przepisów, tak by wydłużyć cały proces. Dla przykładu rozporządzenie Ministra Sprawiedliwości z dnia 22.12.2011 r. w sprawie szczegółowego trybu postępowania w sprawach o opróżnienie lokalu lub pomieszczenia albo o wydanie nieruchomości (Dz. U. z 2012 r. poz. 11) wskazuje, że przed wykonaniem tytułu wykonawczego (aktu notarialnego opatrzonego klauzulą wykonalności), komornik wysłuchuje dłużnika i doręcza mu wezwanie. Przepis ten jednak nie przewiduje sytuacji, w której dłużnik np. odmawia lub unika uczestniczenia w tej czynności. Jest to furtka dla nieuczciwych najemców".

23 Brzmienie art. $1046 \$ 4$ k.p.c. zostało zmienione przez ustawę z 22 marca 2018 r. o zmianie ustawy o finansowym wsparciu tworzenia lokali socjalnych, mieszkań chronionych, noclegowni i domów dla bezdomnych, ustawy o ochronie praw lokatorów, mieszkaniowym zasobie gminy i o zmianie Kodeksu cywilnego oraz niektórych innych ustaw (Dz. U. poz. 756). Zgodnie z nowym brzmieniem tego przepisu, wykonując obowiązek opróżnienia lokalu służącego zaspokojeniu potrzeb mieszkaniowych dłużnika na podstawie tytułu wykonawczego, z którego nie wynika uprawnienie dłużnika do zawarcia umowy najmu socjalnego lokalu lub prawo do lokalu zamiennego, komornik usunie dłużnika do innego lokalu lub pomieszczenia, do którego dłużnikowi przysługuje tytuł prawny i w którym może on zamieszkać. Jeżeli dłużnikowi nie przysługuje tytuł 
podstawie tytułu wykonawczego, z którego nie wynika prawo dłużnika do lokalu socjalnego lub zamiennego, komornik usuwa dłużnika do innego lokalu lub pomieszczenia, do którego dłużnikowi przysługuje tytuł prawny i w którym może zamieszkać (chodzić tu może w szczególności o lokal wskazany przez najemcę w oświadczeniu, o którym mowa w art. 19a ust. 2 pkt 2 lub art. 19a ust. 3 u.o.p.l.). W przypadku braku takiego lokalu lub pomieszczenia byłemu najemcy okazjonalnemu nie przysługuje prawo do pomieszczenia tymczasowego. Zgodnie bowiem $z$ art. 25 d pkt 2 u.o.p.l. prawo do tymczasowego pomieszczenia nie przysługuje dłużnikowi, jeżeli został on zobowiązany do opróżnienia lokalu zajmowanego na podstawie umowy najmu okazjonalnego, której zawarcie zostało zgłoszone zgodnie z art. 19b ust. 1 u.o.p.l. (zgłoszone naczelnikowi urzędu skarbowego właściwemu ze względu na miejsce zamieszkania wynajmującego w terminie $14 \mathrm{dni}$ od dnia rozpoczęcia najmu okazjonalnego). W takim przypadku (zgodnie $\mathrm{z}$ art. $1046 \$ 5^{1}$ k.p.c.) komornik usuwa najemcę okazjonalnego do noclegowni, schroniska lub innej placówki zapewniającej miejsca noclegowe, wskazanej na wniosek komornika przez gminę właściwą ze względu na miejsce położenia lokalu podlegającego opróżnieniu ${ }^{24}$.

Eksmisja byłego najemcy okazjonalnego następuje zatem do lokalu wskazanego przez niego w oświadczeniu (o którym mowa w art. 19a ust. 2 pkt 2 lub ust. 3 u.o.p.l.), innego lokalu lub pomieszczenia, do którego byłemu najemcy przysługuje tytuł prawny i w którym może on zamieszkać bądź do noclegowni, schroniska lub innej placówki zapewniającej miejsca noclegowe. Byli najemcy okazjonalni nie są zatem eksmitowani „na bruk”25.

prawny do innego lokalu lub pomieszczenia, w którym może zamieszkać, komornik wstrzyma się z dokonaniem czynności do czasu, gdy gmina właściwa ze względu na miejsce położenia lokalu podlegającego opróżnieniu, na wniosek komornika, wskaże dłużnikowi tymczasowe pomieszczenie. Zmiana brzmienia tego przepisu wejdzie w życie w dniu 21 kwietnia 2019 r.

24 K. Zdun-ZaŁęSKa, op. cit., s. 170; E. BońCZAK-KucharCZyK, op. cit., s. 338; R. Dziczek, Ochrona..., s. 147; Tenże, Prawo..., s. 405; J. Chaciński, op. cit., s. 155; P. SŁawicki, P. Widerski, Najem..., cz. II, s. 411-412; J. PANowicz-Lipska, op. cit., s. 177.

25 Szerzej kwestie tę omawiają P. SŁAWICKI, P. Widerski (Najem..., cz. II, s. 411-412). 
Warto w tym miejscu także zauważyć, że do najmu okazjonalnego lokalu nie ma zastosowania przepis art. 14 u.o.p.l. (dotyczący uprawnienia lub jego braku do otrzymania lokalu socjalnego) oraz art. 16 u.o.p.l. (dotyczący tzw. moratorium zimowego, tj. zakazu przeprowadzania eksmisji w okresie ochronnym, trwającym od 1 listopada do 31 marca) ${ }^{26}$.

Nawiązując do rozważań zawartych w poprzednim artykule ${ }^{27}$, należy w tym miejscu wskazać, że zgodnie z art. 19b ust. 3 u.o.p.l., w przypadku niedopełnienia obowiązku, o którym mowa w art. 19b ust. 1 u.o.p.l., nie stosuje się przepisów art. 19c i 19d tej ustawy. Z związku z tym omawiane powyżej regulacje dotyczące możliwości wypowiedzenia najmu okazjonalnego w związku z niedopełnieniem przez najemcę obowiązku, o którym mowa w art. 19a ust. 3 u.o.p.l., oraz dotyczące procedury dochodzenia opróżnienia lokalu w drodze postępowania egzekucyjnego na podstawie zaopatrzonego w klauzulę wykonalności aktu notarialnego, o którym mowa w art. 19a ust. 2 pkt 1 u.o.p.l., znajdą zastosowanie jedynie w przypadku dokonania przez wynajmującego zgłoszenia zawarcia umowy najmu okazjonalnego lokalu właściwemu ze względu na miejsce zamieszkania wynajmującego naczelnikowi urzędu skarbowego, w terminie 14 dni od dnia rozpoczęcia najmu. W przeciwnym wypadku wypowiedzenie umowy najmu okazjonalnego lokalu w oparciu o art. 19d ust. 5 u.o.p.l. będzie niemożliwe (znajdzie natomiast zastosowanie ogólna regulacja u.o.p.l. dotycząca wypowiedzenia umowy), a przymusowe opróżnienie lokalu będzie wymagało wytoczenia przez wynajmującego powództwa o eksmisję, która przeprowadzona zostanie w trybie art. $1046 \$ 4$ k.p.c. (zastosowanie znajdą wówczas także przepisy art. 14 i 16 u.o.p.1.) $)^{28}$.

26 E. Bończak-KuCharCZy K, op. cit., s. 329; J. PANOWICZ-Lipska, op. cit., s. 174; M. Walasik, op. cit., s. 96; D. Piwowarczy K, op. cit., s. 37; J. Piech, op. cit., s. 195. P. SŁAWICKI, P. Widerski (Najem..., cz. II, s. 411) zauważają w związku z tym, że „w stosunku do takich najemców, co do zasady, została więc wyłączona szczególna ochrona związana $z$ ich wyjątkową sytuacją rodzinną (np. ciąża) lub majątkową (statusem bezrobotnego) czy też terminem przeprowadzenia eksmisji (okresem zimowym)".

27 A. Mróz, Zgłoszenie..., s. 29-33.

28 K. Zdun-ZaŁęSKA, op. cit., s. 142 i 148; J. CHACIŃsKi, op. cit., s. 155; M. WALAsiK, op. cit., s. 120. T. LECHOwicz (op. cit., s. 34) zauważa, że „aby (...) właściciel mógł skorzystać z 'szybkiej ścieżki eksmisyjnej', zawarcie umowy musi zostać zgłoszone do 
Odwołując się z kolei do zawartych w pierwszym artykule rozważań dotyczących kaucji, od wpłacenia której może być uzależnione zawarcie umowy najmu okazjonalnego lokalu ${ }^{29}$, należy zauważyć, że zgodnie $\mathrm{z}$ art. 19a ust. 4 u.o.p.l. kaucja ta zabezpiecza pokrycie należności z tytułu najmu okazjonalnego lokalu przysługujących właścicielowi w dniu opróżnienia lokalu oraz ewentualnych kosztów egzekucji obowiązku opróżnienia lokalu. Do wskazanych w tym przepisie kosztów egzekucji obowiązku opróżnienia lokalu można zaliczyć w szczególności: opłatę sądową od wniosku o nadanie klauzuli wykonalności aktowi notarialnemu, w którym najemca poddał się egzekucji i zobowiązał się do opróżnienia i wydania lokalu używanego na podstawie umowy najmu okazjonalnego lokalu w terminie wskazanym w żądaniu, o którym mowa w art. 19d ust. 2 u.o.p.l., wynagrodzenie komornika za prowadzenie postępowania egzekucyjnego oraz inne wydatki związane z wykonaniem opróżnienia lokalu (np. koszty usunięcia z lokalu pozostawionych przez najemcę rzeczy). Koszty te mogą zatem zostać pokryte z kwoty wpłaconej przez najemcę tytułem kaucji. Trzeba jednak podkreślić, że kaucja zabezpiecza pokrycie jedynie tych kosztów egzekucji obowiązku opróżnienia lokalu, które zostały faktycznie poniesione przez wynajmującego ${ }^{30}$.

\section{UWAGI KOŃCOWE}

Podsumowując rozważania zawarte w tym oraz poprzednich artykułach, należy stwierdzić, że umową najmu okazjonalnego lokalu jest

urzędu skarbowego - jest to warunek, bez którego sąd nie wyda klauzuli wykonalności i zastosowanie będą miały normalne przepisy o postępowaniu eksmisyjnym". M. WAgemann (op. cit., s. 12) zaważa, że dokonanie przedmiotowego zgłoszenia to „warunek sine qua non wykorzystania uproszczonej procedury egzekwowania wobec najemcy obowiązku opróżnienia zajmowanego lokalu, która stanowi istotę instytucji najmu okazjonalnego".

29 A. Mróz, Umowa..., s. 127-129.

30 Ibidem, s. 128 oraz wskazana tam literatura. Na możliwość pokrycia powyższych kosztów z wpłaconej przez najemcę kaucji zwraca także uwagę J. PIECH, op. cit., s. 194. 
szczególnego rodzaju umowa najmu lokalu mieszkalnego, zawarta na czas oznaczony - nie dłuższy niż 10 lat. Umowa ta zawierana jest przez wynajmującego (którym de lege lata może być tylko osoba fizyczna, nieprowadząca działalności gospodarczej w zakresie wynajmowania lokali) z najemcą, który poddaje się egzekucji (w formie aktu notarialnego, zgodnie z art. $777 \$ 1$ pkt 4 k.p.c.) i zobowiązuje się do opróżnienia i wydania lokalu używanego na podstawie umowy najmu okazjonalnego w określonym terminie oraz wskazuje inny lokal, w którym będzie mógł zamieszkać w przypadku wykonania egzekucji obowiązku opróżnienia lokalu używanego na podstawie umowy najmu okazjonalnego, jak również przedstawia zgodę właściciela lub osoby posiadającej inny tytuł prawny do wskazanego lokalu na zamieszkanie w nim najemcy i osób z nim zamieszkujących w lokalu używanym na podstawie umowy najmu okazjonalnego ${ }^{31}$.

W treści umowy najmu okazjonalnego lokalu muszą znaleźć się postanowienia dotyczące wysokości czynszu. Mogą w niej również znaleźć się postanowienia dotyczące ewentualnych innych opłat, do pobierania których uprawniony będzie wynajmujący, zasad podwyższania czynszu oraz postanowienia dotyczące kaucji, od wpłacenia której uzależnione może być zawarcie umowy.

31 M. NazAR, Najem okazjonalny, [w:] Współczesne problemy prawa prywatnego. Księga pamiątkowa ku czci Profesora Edwarda Gniewka, red. J. KoŁACZYŃsKI, P. MACHNikowski, Warszawa 2010, s. 411-412; J. PAnowiCz-LipskA, op. cit., s. 174. K. ZDUN-ZAŁĘSKA (op. cit., s. 139) trafnie zauważa, że „wymóg załączenia tych oświadczeń jako załączników do umowy najmu okazjonalnego oznacza, że zawarcie takiej umowy jest dopuszczalne tylko z najemcą mającym możliwość zamieszkania w innym lokalu”. E. BońcZAK-KuсHARCZYк (op. cit., s. 324) wskazuje z kolei, że konieczność wskazania przez najemcę innego lokalu, w którym będzie on mógł zamieszkać w przypadku wykonania egzekucji obowiązku opróżnienia lokalu, „uniemożliwia zawarcie umowy o najem okazjonalny z najemcą, który nie ma możliwości zamieszkania w żadnym innym lokalu”. P. SŁAWICKI, P. WIDERSKI (Najem..., cz. II, s. 412) stwierdzają, że „forma najmu okazjonalnego jest adresowana do szczególnej grupy najemców, którzy mają potrzebę stosunkowo niedługiego korzystania z lokalu, a do tego mogą wskazać lokal, w którym będą mogły zamieszkać, w przypadku zakończenia umowy najmu”. 
Umowa najmu okazjonalnego lokalu jest umową konsensualną, dwustronnie zobowiązującą, odpłatną i wzajemną ${ }^{32}$. Jest ona szczególnym (kwalifikowanym) rodzajem umowy najmu lokalu, do której zastosowanie znajdują odpowiednie przepisy u.o.p.l. (art. 19a-19e oraz art. $25 \mathrm{~d}$ pkt 2 u.o.p.l.), niektóre inne przepisy ustawy o ochronie praw lokatorów... (wskazane w treści art. 19e u.o.p.l.) oraz przepisy kodeksu cywilnego o najmie ${ }^{33}$.

Od „zwykłej” umowy najmu lokalu mieszkalnego najem okazjonalny różni się tym, że nie znajduje do niego zastosowania większość (chroniących najemcę) przepisów u.o.p.l. Istotą najmu okazjonalnego jest zatem wyłączenie go spod reżimu u.o.p.l., a przez to znaczne wzmocnienie pozycji wynajmującego i zapewnienie mu możliwości przeprowadzenia sprawnego i skutecznego opróżnienia lokalu po wygaśnięciu najmu okazjonalnego (usunięcie z lokalu byłego najemcy jest bowiem możliwe bez konieczności przeprowadzania postępowania sądowego i uzyskania wyroku eksmisyjnego oraz zapewnienia najemcy innego lokalu czy pomieszczenia tymczasowego ${ }^{34}$.

32 P. SŁawicki, P. Widerski, Najem..., cz. I, s. 352; S. Minkina, Najem okazjonalny lokalu w świetle ustawy z 17 grudnia 2009 r., «Radca Prawny» 117/2011 - Dodatek Naukowy, s. 24 D.

33 P. SŁawicki, P. Widerski (Najem..., cz. I, s. 352) wskazują, że „umowę najmu okazjonalnego należy zakwalifikować jako podtyp nazwanej umowy najmu lokalu, do której przez analogię należy stosować przepisy KC regulujące najem lokalu (art. 680$692 \mathrm{KC}$ ), zatem umowa najmu okazjonalnego to umowa, w której wynajmujący (...) zobowiązuje się oddać najemcy lokal służący do zaspokajania potrzeb mieszkaniowych do używania przez czas oznaczony, nie dłuższy niż 10 lat, a najemca zobowiązuje się płacić wynajmującemu umówiony czynsz”. K. ZDUn-ZAŁĘSKA (op. cit., s. 143) zauważa, że „przepisy o najmie okazjonalnym tworzą szczególny reżim prawny, stanowiący wyjątek od ogólnych zasad najmu lokali mieszkalnych (...)”.

34 M. NazAr, op. cit., s. 412. P. SŁAWicki, P. Widerski (Najem..., cz. I, s. 355-356) wskazują, że „formalna dystynkcja najmu okazjonalnego lokali w stosunku do zwykłego najmu lokali sprowadza się do uproszczonej realizacji prawa wynajmującego do opróżnienia lokalu w sytuacji, gdy najemca nie chce go dobrowolnie opuścić. Funkcją tego najmu jest ograniczenie ochrony najemcy. Wynajmujący nie musi wytaczać przeciwko najemcy powództwa o opróżnienie lokalu, może on bowiem prowadzić egzekucję na podstawie aktu notarialnego, zaopatrzonego w klauzulę wykonalności, w którym dłużnik poddał się egzekucji”. J. PıEch (op. cit., s. 197) zauważa, że 
Najem okazjonalny lokalu ogranicza możliwość uchylania się najemców od eksmisji, przez co zwiększa bezpieczeństwo prawne wynajmujących. Konstrukcja ta może zatem chronić wynajmujących przed sytuacjami, w których nierzetelni lub uciążliwi najemcy nadużywają przysługującej im ochrony (wynikającej z regulacji u.o.p.l.) i przez długi czas (np. nie płacąc czynszu czy też zajmując lokal po wygaśnięciu najmu) unikają eksmisji ${ }^{35}$.

Najem okazjonalny w istotny sposób zabezpiecza jednak także interes najemcy, który decydując się na zawarcie takiej umowy, uzyskuje pewność, że wynajmujący (oprócz czynszu i opłat niezależnych od właściciela, czyli opłat za dostawy do lokalu energii, gazu, wody oraz odbiór ścieków, odpadów i nieczystości ciekłych) będzie od niego pobierał jedynie opłaty wskazane w treści umowy, jak również - i co ważniejsze - że w trakcie trwania najmu czynsz będzie mógł zostać podwyższony jedynie w przypadkach i na warunkach określonych w umowie ${ }^{36}$.

Objęcie stosunku prawnego powstałego na podstawie umowy najmu okazjonalnego lokalu pełną regulacją dotyczącą tego typu umowy oraz wyłączenie go spod większości przepisów u.o.p.l. jest jednak uzależnione od dokonania przez wynajmującego zgłoszenia zawarcia tej umowy naczelnikowi urzędu skarbowego właściwemu ze względu na miejsce

„W efekcie poddania się egzekucji z aktu notarialnego wierzyciel uzyskuje zaspokojenie roszczenia bez konieczności występowania na drogę postępowania sądowego. Nadto z obraniem opisanej ścieżki egzekucyjnej wiążą się dodatkowe korzyści dla wierzyciela w aspekcie gospodarczym. Nie musi on ponosić dodatkowych kosztów postępowania rozpoznawczego, a jego roszczenie zostaje zaspokojone znacznie szybciej, niż jeśli by korzystał z tradycyjnej drogi sądowej. (...) Co więcej, poddanie się egzekucji aktem notarialnym powoduje odciążenie wymiaru sprawiedliwości poprzez wyodrębnienie grupy czynności notarialnych wykonywanych alternatywnie w stosunku do działań sądowego wymiaru sprawiedliwości”.

35 E. SiwińsKA-BECK (op. cit., s. 44), opisując genezę konstrukcji najmu okazjonalnego w polskim prawie, wskazuje, że „bezsprzecznie sama regulacja umowy najmu zawarta w KC oraz przepisy ustawy OchrPrLokU stanowiły przeszkodę do swobodnego i płynnego rozwoju instytucji najmu lokali mieszkalnych z uwagi na to, że jej przepisy roztaczały szeroki parasol ochronny nad niesumiennymi najemcami, nie dając wynajmującym w zasadzie żadnych skutecznych narzędzi ochrony przysługujących im praw".

36 A. Mróz, Umowa..., s. 125-127 oraz wskazana tam literatura. 
zamieszkania wynajmującego, w terminie 14 dni od dnia rozpoczęcia najmu. W przypadku niedokonania przedmiotowego zgłoszenia przez takiego wynajmującego, zawartą umowę traktuje się jak „zwykłą” umowę najmu lokalu mieszkalnego, zawartą na czas oznaczony, do której zastosowanie znajduje regulacja u.o.p.l.

Przyjęcie przez ustawodawcę rozwiązania, zgodnie z którym reżim prawny umowy najmu okazjonalnego uzależniony jest od dokonania przez wynajmującego przedmiotowego zgłoszenia, budzi uzasadnione wątpliwości i jest obiektem zdecydowanej krytyki. Regulacji tej zarzuca się fiskalizm i ukierunkowanie nie na kwestie mieszkaniowe, ale na zabezpieczenie dochodów państwa z podatków ${ }^{37}$.

37 E. BończAK-KuCHARCZYк (op. cit., s. 321) zauważa, że przepisy uzależniające skuteczność umowy najmu okazjonalnego i właściwy dla niej reżim prawny od dokonania przez wynajmującego zgłoszenia jej zawarcia właściwemu naczelnikowi urzędu skarbowego „wprowadzają niespotykane dotychczas zasady, że ten sam najem może być najmem okazjonalnym, ale może też nim nie być, w zależności od zachowania wynajmującego po podpisaniu umowy najmu okazjonalnego. Rozwiązanie to należy uznać za nieprawidłowe, gdyż charakter umowy objawia się jakiś czas po jej zawarciu, niezależnie od tego, w jaki sposób sformułowano jej postanowienia, a jedna ze stron umowy (najemca) nie ma na to wpływu (co przeczy równouprawnieniu stron zawierających umowę)”. R. Dziczek (Ochrona..., s. 146-147, oraz Prawo..., s. 404-405) stwierdza, że „w ten sposób umowę ex definitione okazjonalnego pozbawiono zasadniczych cech właściwych, które funkcjonowały od 1 stycznia 2005 r. do 28 stycznia 2010 r., jeżeli właściciel zaniechał w czasie wyznaczonym w art. 19b ust. 1 u.o.p.l. zgłoszenia jej do urzędu skarbowego. Ten regres prawodawczy należy ocenić zdecydowanie krytycznie. Racje, które przyświecały takiemu rozwiązaniu, godzą przede wszystkim w konstytucyjnie zagwarantowane prawa właściciela do jednakowej ochrony (art. 64 ust. 2 Konstytucji RP). Względy fiskalne nie mogą określonych kategorii właściciela pozbawiać praw, które ustawa przewiduje w warunkach oddania mieszkania w najem okazjonalny. Należy przy tym zauważyć, że niezgłoszenie, w warunkach art. 19b ust. 1 u.o.p.l., umowy do urzędu skarbowego nie jest równoznaczne z uchylaniem się przez właściciela od płacenia podatku. Z kolei wiązanie dwóch sfer - podatkowej i ochrony praw lokatora i właściciela - w formule prostej implikacji, że zaniechanie jednego z elementów rozwiązania rzutuje na byt prawnie istotny danego stosunku cywilnego - ze sfery prawa mieszkaniowego, sprowadza państwo do roli gwaranta praw podatników, a nie obywateli”. J. CHACıŃski (op. cit., s. 155) stwierdza, że „regulacja ta ma motyw czysto fiskalny". 
Obowiązujące unormowania dotyczące najmu okazjonalnego lokalu są jednak krytykowane także z innych powodów. Wskazuje się na wyjątkową kazuistyczność przyjętych rozwiązań oraz nadmierne sformalizowanie czynności dokonywanych przy zawieraniu tej umowy, co de facto może zniechęcać do jej zawarcia ${ }^{38}$.

Między innymi z powyższych względów konstrukcja najmu okazjonalnego, obecna w naszym systemie prawnym już od wielu lat - wbrew oczekiwaniom ustawodawcy, wyrażanym w uzasadnieniach kolejnych nowelizacji u.o.p.l. - nie cieszy się dużą popularnością. Wpływ na to ma między innymi chęć uniknięcia przez strony dodatkowych kosztów oraz formalności związanych z koniecznym udziałem notariusza przy sporządzaniu obowiązkowych załączników do umowy najmu okazjonalnego, ale też - co warto zauważyć - niechęć części z wynajmujących do ujawniania osiąganych z najmu dochodów i płacenia od nich podatków ${ }^{39}$.

Wciąż niewielka liczba zawieranych umów najmu okazjonalnego wynika także ze skromnej świadomości prawnej znacznej części uczestników rynku najmu lokali mieszkalnych w Polsce. Nieznajomość obowiązujących przepisów prawa, zwłaszcza przez wynajmujących mieszkania, a co za tym idzie nieświadomość ewentualnych niebezpieczeństw wiążących się z możliwością wykorzystania przez nieuczciwego najemcę uprawnień wynikających z u.o.p.l., czy też nieufność wobec szerzej nieznanej i nieczęsto stosowanej konstrukcji, skutkuje

38 R. Dziczek, Ochrona..., s. 143; Tenże, Prawo..., s. 401; M. Nazar, op. cit., s. 417.

39 Na wciąż małą popularność najmu okazjonalnego zwraca także uwagę M. KAMIŃsKi (Najem okazjonalny w praktyce, «Nieruchomości» 2/2016, s. 39-40). Z danych podanych w dniu 19 listopada 2014 r. przez Polską Federację Rynku Nieruchomości (w ramach podsumowania akcji BEZPIECZNY NAJEM, przeprowadzonej w 2014 r.) wynika, że uczestnicy rynku unikają umów najmu okazjonalnego - aż $80 \%$ z biorących udział w badaniu biur nieruchomości przygotowało mniej niż 5\% tego rodzaju umów, przy czym 43\% badanych pośredników jako powód unikania umów najmu okazjonalnego wskazało niechęć do ponoszenia przez klientów dodatkowych kosztów; 33\% wskazało brak u klientów wystarczającej wiedzy o najmie okazjonalnym; natomiast $24 \%$ wskazało na chęć uniknięcia przez klientów dodatkowych formalności. Informacja PFRN dostępna pod adresem: http://pfrn.pl/page/1824 (dostęp: 23 stycznia 2019 r.). 
zdecydowanie rzadszym zawieraniem umów najmu okazjonalnego niż „Zwykłych” umów najmu lokali mieszkalnych ${ }^{40}$.

W ostatnich latach zauważalny jest jednak wzrost świadomości prawnej dotyczącej najmu okazjonalnego lokali i liczby zawieranych tego typu umów. Przyczyniają się do tego niewątpliwie publikacje prasowe oraz akcje informacyjne, wyjaśniające istotę tej konstrukcji prawnej i jej znaczenie dla zabezpieczenia interesów stron umowy najmu - zarówno wynajmującego, jak i najemcy. Bardzo istotną rolę w tym procesie odgrywa także „profesjonalizacja” rynku najmu lokali mieszkalnych wzrost liczby zawieranych umów najmu okazjonalnego wiąże się bowiem bezpośrednio z coraz częstszą obsługą tego typu transakcji przez prawników, pośredników oraz wyspecjalizowane agencje obsługujące najem lokali mieszkalnych ${ }^{41}$.

$40 \quad$ Z doświadczenia zawodowego autora, związanego m.in. z obsługą prawną rynku najmu lokali mieszkalnych i komercyjnych oraz pracą naukowo-dydaktyczną, wynika, że znaczna część uczestników rynku najmu lokali mieszkalnych (zarówno wynajmujących, jak i najemców) nie zna przepisów u.o.p.l., a co za tym idzie, nie uświadamia sobie wynikających z nich konsekwencji dla powstałego na podstawie „Zwykłej” umowy najmu lokalu mieszkalnego stosunku prawnego (w szczególności dotyczących samej możliwości, jak i terminów wypowiedzenia takiej umowy, czy też eksmisji najemcy). W wielu przypadkach nieznajomość przepisów u.o.p.l. prowadzi do formułowania przez strony postanowień zawieranych przez nie umów najmu w sposób sprzeczny z bezwzględnie obowiązującymi przepisami prawa (na przykład w zakresie powodów i terminów wypowiedzenia umowy najmu lokalu mieszkalnego czy zaspokojenia określonych roszczeń wynajmującego z wpłaconej przez najemcę kaucji). Na kwestię tę zwraca także uwagę M. KAMıŃsKi (op. cit., s. 38).

41 H. Milewska-Wilk, Jeszcze więcej mieszkań na wynajem - dane z podatków 2016, «Nieruchomości» 3/2018, s. 2. Z danych podanych w dniu 27 października 2015 r. przez Polską Federację Rynku Nieruchomości (w ramach podsumowania akcji BEZPIECZNY NAJEM, przeprowadzonej w 2015 r.) wynika, że uczestnicy rynku najmu lokali mieszkalnych przekonują się do umów najmu okazjonalnego - aż w 23\% z biorących udział w badaniu biur nieruchomości przygotowano pomiędzy 21 a $50 \%$ umów najmu okazjonalnego, w 15\% biur nieruchomości było to od 6 do 20\% umów najmu okazjonalnego, natomiast w $62 \%$ z biur nieruchomości było to mniej niż $5 \%$ umów najmu okazjonalnego. W przypadku 38\% z biur nieruchomości zauważalny był wzrost liczby zawieranych umów najmu okazjonalnego w porównaniu z badaniami przeprowadzonymi w roku poprzednim. Informacja PFRN dostępna pod adresem: http://pfrn.pl/page/1976 (dostęp: 23 stycznia 2019 r.). Na sukcesywny wzrost liczby 
Trzeba jednak zauważyć, że pomimo stałego wzrostu liczby zawieranych umów najmu okazjonalnego lokalu ich udział w rynku najmu lokali mieszkalnych w Polsce wciąż jest znikomy, a sama konstrukcja najmu okazjonalnego pozostaje nadal szerzej nieznana i niedoceniana ${ }^{42}$.

Kończąc rozważania dotyczące najmu okazjonalnego, należy zauważyć, że strony zamierzające zawrzeć umowę najmu lokalu mieszkalnego mogą zdecydować się na zawarcie umowy najmu na zasadach ogólnych („zwykłej” umowy najmu lokalu mieszkalnego), która w pełni podlegać będzie reżimowi u.o.p.l. (w związku z czym szczególnej ochronie podlegać będzie najemca), bądź na zawarcie umowy najmu okazjonalnego lokalu, która to umowa - pod warunkiem spełnienia wszystkich przewidzianych przepisami wymogów - wyłączona będzie spod działania większości przepisów u.o.p.l., a jej reżim prawny opierać się będzie na regulacji art. 19a-19e u.o.p.l. oraz przepisach kodeksu cywilnego o najmie (w związku z czym wzmocniona - w stosunku do zasad ogólnych - będzie pozycja wynajmującego $)^{43}$.

Istotne jest jednak, aby decyzja dotycząca wyboru określonej formuły najmu lokalu została podjęta $\mathrm{z}$ pełną świadomością różnic pomiędzy najmem „zwykłym” a okazjonalnym i przy uwzględnieniu wynikających z tych stosunków prawnych praw i obowiązków obu stron.

zawieranych umów najmu okazjonalnego lokalu wskazuje także E. SiwıŃsKA-BECK (op. cit., s. 44).

42 Według danych Ministerstwa Finansów: w 2010 r. umowy najmu okazjonalnego zarejestrowało 1480 podatników; w 2011 r. - 2255 podatników; w 2012 r. - 3093 podatników; w 2013 r. - 4178 podatników; w 2014 r. - 5116 podatników; w 2015 r. - 6574 podatników; w 2016 r. - 11256 podatników; w 2017 r. - 16597 podatników. W 2016 r. było to $1,7 \%$ wszystkich podatników wykazujących dochody z najmu; w 2017 r. było to 2,32\% wszystkich podatników wykazujących dochody z najmu. Informacje dostępne pod adresem: https://finanse-arch.mf.gov.pl/pit/statystyki (dostęp: 23 stycznia 2019 r.).

43 P. SŁAwicki, P. Widerski, Najem..., cz. II, s. 412. Zwięzłe porównanie „Zwykłej” umowy najmu lokalu mieszkalnego oraz umowy najmu okazjonalnego lokalu (uwzględniające m.in. kwestie czasu trwania umowy, formy jej zawarcia, koniecznych załączników, egzekucji obowiązku opróżnienia lokalu, czynszu i kaucji) prezentuje w formie tabeli E. SiwińsKA-BEck (op. cit., s. 47). 
ZAKOŃCZENIE NAJMU OKAZJONALNEGO I OPRÓŻNIENIE LOKALU

\section{Streszczenie}

Artykuł jest ostatnim z trzech artykułów prezentujących szczegółowe rozważania dotyczące konstrukcji najmu okazjonalnego lokalu oraz jej praktycznego znaczenia dla funkcjonowania rynku najmu lokali mieszkalnych w Polsce.

W artykule przedstawiono rozważania dotyczące zakończenia najmu okazjonalnego i procedury opróżnienia lokalu (eksmisji byłego najemcy). W zakończeniu wskazano najważniejsze wnioski, podsumowujące rozważania zawarte we wszystkich trzech opracowaniach.

\section{Termination of Occasional Tenancy and the Vacation of THE PREMISES}

\section{Summary}

This is the last of three articles presenting issues relating to the structure of occasional tenancy of premises and its practical significance for the residential rental market in Poland.

The article discusses the issues relating to termination of occasional tenancy and procedures for vacating the premises (eviction). It ends with a summary of the conclusions drawn from all three articles.

Słowa kluczowe: umowa najmu; najem okazjonalny lokalu; opróżnienie lokalu; eksmisja najemcy okazjonalnego.

Keywords: tenancy contract; occasional tenancy of premises; vacation of the premises; eviction of an occasional tenant. 


\section{Literatura}

BońCZAK-KucharCzyк E., Ochrona praw lokatorów i najem lokali mieszkalnych. Komentarz, Warszawa 2013.

Chaciński J., Ochrona praw lokatorów. Komentarz, Warszawa 2013.

Daniluk D., Najem okazjonalny w świetle nowelizacji Kodeksu postępowania cywilnego $z 31$ sierpnia 2011 r., «Radca Prawny» 125/2012 - Dodatek Naukowy, s. 15-17.

Doliwa A., Najem lokali. Komentarz, Warszawa 2014.

Doliwa A., Prawo mieszkaniowe. Komentarz, Warszawa 2012.

Dziczek R., Ochrona praw lokatorów. Dodatki mieszkaniowe. Komentarz. Wzory pozwów, Warszawa 2012.

Dziczek R., Prawo mieszkaniowe w praktyce. Wzory pozwów i wniosków sadowych, Warszawa 2012.

KAMIŃSKi M., Najem okazjonalny w praktyce, «Nieruchomości» 2/2016, s. 38-40.

KAŹmierCzyк A., Najem okazjonalny lokali mieszkalnych $w$ świetle zasady swobody umów, [w:] Ustawowe ograniczenia swobody umów. Zagadnienia wybrane, red. B. Gnela, Warszawa 2010, s. 500-513.

Lechowicz T., Sytuacja wynajmu mieszkań na rynku nieruchomości w Polsce, «Nieruchomości» 5/2011, s. 34-38.

Minkina S., Najem okazjonalny lokalu w świetle ustawy z 17 grudnia 2009 r., «Radca Prawny» 117/2011 - Dodatek Naukowy, s. 22-24.

Milewska-Wilk H., Jeszcze więcej mieszkań na wynajem - dane z podatków 2016, «Nieruchomości» 3/2018, s. 27-29.

Mróz A., Umowa najmu okazjonalnego lokalu, «Zeszyty Prawnicze»16.4/2016, s. $105-132$.

Mróz A., Zgłoszenie najmu okazjonalnego lokalu naczelnikowi urzędu skarbowego, «Zeszyty Prawnicze» 18.1/2018, s. 25-38.

NazAr M., Najem okazjonalny, [w:] Współczesne problemy prawa prywatnego. Księga pamiątkowa ku czci Profesora Edwarda Gniewka, red. J. KoŁACzyŃSKi, P. Machnikowski, Warszawa 2010, s. 407-418.

Panowicz-Lipska J. (red.), System Prawa Prywatnego. Prawo zobowiąań część szczegółowa, VIII, Warszawa 2011.

Piech J., Prowadzenie egzekucji z najmu okazjonalnego, [w:] Tendencje prawa materialnego i procesowego cywilnego, red. E. MarszaŁKowsKa-Krześ, Wrocław 2017, s. 189-198. 
PiwowarCzy K D., Najem okazjonalny. Czynności notarialne przy zawieraniu umowy najmu okazjonalnego. Analiza aktualnego stanu prawnego, «Jurysta» 1/2010, s. 33-37.

Siwı́́sKA-BECK E., Najem okazjonalny - wybrane zagadnienia praktyczne, «Nieruchomości» 7/2017, s. 44-47.

SŁAWicki P., Widerski P., Najem okazjonalny lokali - cz. I, «Monitor Prawniczy» 7/2012, s. 350-357.

SŁaWicki P., Widerski P., Najem okazjonalny lokali - cz. II, «Monitor Prawniczy» 8/2012, s. 406-415.

Wagemann M., Najem okazjonalny, «Nieruchomości» 8/2013, s. 11-13.

Walasıк M., Poddanie się egzekucji przez najemcę okazjonalnego, «Rejent» 3/2011, s. 95-121.

ZaWAdZKa J., Najem instytucjonalny lokali mieszkalnych, «Monitor Prawniczy» 21/2017, s. 1133-1146.

ZDUN-ZAŁĘSKA K., Ustawa o ochronie praw lokatorów, mieszkaniowym zasobie gminy i o zmianie Kodeksu cywilnego. Komentarz, Warszawa 2014. 